Univerzitet Mediteran, Fakultet vizuelnih umjetnosti, Podgorica, Crna Gora

DOI 10.5937/kultura1339209S

UDK 659.3/.4

$316.774 / .776$

pregledni rad

\title{
PRIMED||J-POSREDNICI |LL KROJAĆI DRUŠTVA
}

Sažetak: Problemi u konceptualizaciji i definisanju odnosa s javnostima i razvoja profesije PR iz tridesetih godina prošlog vijeka potrajali su, evo i do danas, u naporima praktičnog i teoretskog odvajanja ove profesije-discipline od poistovjećivanja sa novinskim agencijama i propagandom kao i nekim drugim profesijama i disciplinama poput novinarstva, sociologije, istraživanja, ekonomije, marketinga, politikologije. Različiti pristupi u definisanju PR-a i profesije "public relations" su neminovnost pošto još ne postoji jedinstvena definicija koja bi obuhvatila sve aspekte, aktivnosti, zadatke, tendencije, ciljeve i područja sadržana u ovoj profesiji. Posebno je interesantan pristup odnosa sa javnostima, novinarstva i države u savremenom društvu, ne samo na globalnom nivou i u razvijenim državama, nego i u zemljama u tranziciji. Kakva je uloga medija kao moćnih posrednika i PR-a kroz medijske manipulacije, lobista i drugih krojača PR-a i medija ali i društva, kao i promjenljivi trendovi PR kompanija i lobista koji djeluju u tajnosti (poput onih iz grupe Bilderberg) budući da stručnjaci PR smatraju da najbolji PR ne ostavlja nikakve tragove.

Ključne riječi: odnosi sjavnošću, komunikacija, lobiranje, novinarstvo, javna sfera

\section{Uvod}

Poistovjećivanje odnosa s javnošću sa novinskim agencijama i propagandom, početkom prošlog vijeka, kao i sa nekim drugim profesijama i disciplinama poput novinarstva, sociologije, istraživanja, komunikologije, politikologije, ekonomije, marketinga. i danas je vrlo često. Zbog toga su i različiti pristupi u definisanju PR i profesije public relations, jer ne postoji jedinstvena definicija koja bi obuhvatila sve aspekte, aktivnosti, zadatke, tendencije, ciljeve i područja sadržana u ovoj profesiji. Da bi spoznali suštinu odnosa s javnostima i uloge medija neophodno 


\section{VELIZAR SREDANOVIĆ}

je analizirati PR i isprepletenost veza s tim disciplinama. Posebno je u procesu globalizacije u visokorazvijenim, ali i u zemljama u tranzicji, interesantan pristup odnosa sa javnostima, novinarstva i države tj. vlasti u savremenom društvu, jer svrha odnosa s javnošću treba da odgovara svrsi demokratije. Ne manje važno je odgovoriti i na pitanje - kakva je uloga medija kao moćnih posrednika i PR-a kroz medijske manipulacije, lobista i drugih krojača PR-a i medija ali i društva? Prije svega, potrebno je riješiti neke od dilema i problema u konceptualizaciji PR-a i doprinijeti u naporima praktičnog i teoretskog odvajanja ove profesije-discipline od srodnih profesija i nauka.

\section{Definisanje PR-a}

Pokušaji tumačenja pojma i definicije odnosa javnostima ukazuju koliko je teško dati jednostavnu a kamoli sveobuhvatnu definiciju public relations čija se sadržina mijenjala s razvojem civilizacije, društveno-ekonomskih odnosa i razvojem ove profesije. Teza o poboljšanom protoku informacija, odnosno odnosima s javnostima i medijima, tj. novinarstvu koji stvaraju klimu potrebnu za razvoj, posebno nacionalni, mogla bi se razmatrati i teoretisati sa više aspekta kroz prizme više naučnih disciplina.

Problemi u konceptualizaciji i definisanju odnosa s javnošću potiču još od 1923. godine i predavanja, ujedno i prvog priručnika o public relations ${ }^{1}$ (anglosaksonski izraz koji se može prevesti kao odnosi s javnošću) Dr Edvarda L. Bernajsa - Kristalizacija javnog mnijenja(Cristallizing Public Opinion) na prvom kursu za odnose s javnošću Univerziteta u Njujorku posvećenog toj novoj profesiji-disciplini. Tako je praktično počelo i praćenje razvoja odnosa s javnošću, odnosno u početku odvajanje ove profesije od poistovjećivanja sa novinskim agencijama i propagandom, kao i nekim drugim profesijama i disciplinama, koje će potrajati evo i do danas.

Enciklopedia Britannica ${ }^{2}$ pod terminom 'odnosi s javnošću' definiše ,aspekt komunikacije koji obuhvata promovisanje željenog imidža pojedinca ili grupe čiji je cilj da privuče pažnju javnosti.“ Definicija Meksičke deklaracije (iz avgusta 1978.) glasi: „Praksa odnosa s javnošću je vještina i društvena nauka koja analizira kretanja, predviđajući njihove posledice, savjetujući

$1 \mathrm{U}$ daljem tekstu za odnose $\mathrm{s}$ javnošću koristićemo u literatruri uobičajenu skraćenicu PR koja dolazi od public relations. Osim ovog medjunarodnog termina, na francuskom govornom području se koristi naziv Relations publiques, italijanskom, Relazioni pubbliche i njemačkom, Oeffentlichkeitsarbeit.

2 Enciklopedija Britanika 1-10, knjiga 6, (2005) Beograd: Politika, Narodna knjiga, str. 101. 


\section{VELIZAR SREDANOVIĆ}

rukovodstvo jedne organizacije i ostvarujući planirane programe akcija koje će biti u interesu društva i određene organizacije". ${ }^{3}$

Samo je Rex Harlow obrađujući ovu tematiku do 1976. godine spoznao 472 definicije PR.

Shodno genezi i razvoju odnosa s javnošću kao organizovane prakse, čiji počeci sežu početkom dvadesetog vijeka u SAD, nastajale su i razne definicije teoretičara izdato je saopštenje, odnosno poduža zvanična Službena izjava o odnosima s javnošću, komunikacije i PR-a. Međutim, tek 1982. godine nastaje američko udruženje za PR (Public Relations Society of America PRSA), na osnovu mnogih definicija PR-a i opisa prakse PR-a.

Uz pojmovni dio, izjava uključuje i popis aktivnosti, rezultata i znanja potrebnih za vođenje odnosa s javnošću, a na osnovu te izjave su Scott Cutlip, Alen Center i Glen Broom objašnjavajući razvoj pojma kroz bezbrojne pokušaje opisivanja prakse američkih i svjetskih stručnjaka izveli jednostavnu definiciju: „Odnosi s javnošću su funkcija upravljanja koja uspostavlja i održava uzajamno korisne odnose između organizacije i različitih javnosti o kojima ovisi njezin uspjeh ili neuspjeh" ". ${ }^{4}$ Time su mnoge aktivnosti i ciljeve prakse odnosa s javnošću sveli u okvir funkcije upravljanja.

Pored definicija o odnosima sa javnostima i(li) odnosa sa javnošću koje sam detaljno elaborirao u knjizi Javnost i mediji u Crnoj Gori $i^{5}$ za uvod u temu odnosi s javnostima i novinarstvo kao jednu od najkraćih definicija i vrlo interesantnu navodi i kolega R. Udovičić i to kao:,Pozicioniranje organizacije u javnosti““ ${ }^{6}$ $\mathrm{U}$ tom kontekstu, kao i (pra)početaka public relations na tlu Crne Gore, kada se javljaju kao najprostiji oblici jednosmjernog ubjeđivačkog komuniciranja, naveo bih maksimu iz Ljetopisa popa Dukljanina: „Da se dobro svidi a loše odbaci“ kao izvrstan primjer najkraće definicije PR. Upravo, kroz termine i proces, prepoznaju se ne samo intencije već su i opisani elementi odnosa $\mathrm{s}$ javnošću poput tadašnjih svojevrsnih javnih poslova i lobiranja, koji su očigledni u tim počecima stvaranja državnih organizacija kod zetskih Slovena...I danas, kada preovladava moderni koncept odnosa s javnošću, upravo maksima da se dobro svidi a loše odbaci, (kao integralni dio državne administracije iz tih najranijih dana) mogla bi da bude primjer kako se najjednostavnije

3 Blek, S. (1997) Odnosi s javnošću, Beograd: Clio, str. 6.

4 Cutlip, S. M., Center, A. H, and Broom G. M. (2003) Odnosi s javnošću,osmo izdanje; Zagreb: Mate

5 Sredanović, V. (2007) Javnost i mediji u Crnoj Gori, Cetinje: Obod

6 Udovičić, R. (2007) Informatori s različitim ciljevima, Sarajevo: Media plan institut, str. 13 . 
mogu opisati ne samo proces i težnja, već neke i od najbitnijih funkcija odnosa s javnošću, pa i suština same definicije odnosa s javnostima i(li) profesije PR-a u modernom menadžmentu.

Interesantni su i ostali brojni pojedinačni pokušaji mnogih autora da odnose s javnošću definišu na osnovu toka informacija, komunikacija, prakse, plana, akcije, tendencija, ciljeva, istraživanja, upravljanja... Zapostavimo li detalje i preciznosti svih elemenata, pa i ovih definicija PR-a, ne možemo a da ne zaključimo da je do sada istaknuto, pretežno, evolucionističko shvatanje odnosa sa javnostima, pa ćemo pokušati bar djelimično obraditi fenomen PR-a i odnosa s ostalim disciplinama.

\section{PR i druge discipline}

Odnose s javnošću, pa i unutrašnje zakonitosti PR komunikacije mogu se razumijeti samo u okviru globalnih slika stvarnosti i okruženja, a shodno tome i PR, odnosno organizacije u odnosu na spoljni svijet. Aktuelno viđenje PR-a, koje potkrepljuje tezu dosadašnjih napora za povećanje efikasnosti PR komunikacije sa savremenom teorijom i praksom menadžmenta, nije od juče. Traje decenijama. Takoreći od konstatacije Edvarda L. Bernejsa iz predgovora njegove Kristalizacije javnog mnijenja, inače prve knjige o PR-u, koji naglašava stimulisanje naučnog stava spram odnosa s javnostima kao nauke do nauke o komunikaciji 80-tih godina 20-tog vijeka. Tada se ustaljuje gledište o PR-u kao predmetu na visokoškolskim ustanovama koji se naučno istražuje. Iskorak američkih PR nauka i Jamesa E. Gruniga 1990te, sa stanovištem da postoji kritična masa studija iz kojih može nastati jedna nauka o PR, te naučnika o komunikaciji Vinncenta Hazeltona i Carl Botona sa Ilionis State univerziteta (koji su objavili knjigu Teorija Public Relations-a), prethodio je cjelovitijem teoretskom pogledu na PR sa obilježjima naučnog u Evropi, preciznije u Njemačkoj, upravo kod Franza Ronnebergera i Manfreda Ruhla 1992. godine kroz njihovu Teoriju odnosa s javnošću. Višegodišnji, odnosno višedecenijski ignorantski odnos starijih komunikologa i naučnika iz publicistike, do, gotovo poslednje decenije proteklog milenijuma, prema PR-u, sprečavalo je zasnivanje jednog cjelovitog naučno-teorijskog objašnjenja ove nove vrste komunikacije. Otuda i pitanje Ruhla... „da li je PR možda nova forma javnih komunikacija?...“, ali i stanovište, da više nije dovoljno baviti se uzrocima i djelovanjem PR-a već da pažnju treba usmjeriti na sistematična i racionalna istraživanja PR problema, koji su korijen svake društvene komunikacije.

U tekstu koji slijedi, našu pažnju usredsredićemo na nauku o komunikacijama i problematiku istraživanja public relations, kao i odnosima javnosti sa sociologijom i socijalnom psihologijom, 


\section{VELIZAR SREDANOVIĆ}

ekonomijom i marketingom, naukom o politici (upravljanju, lobiranju) i naukom o jeziku s posebnim osvrtom na lingvistiku i retoriku.

\section{PR i nauka o jeziku, lingvistika i retorika}

Politički PR je od svojih početaka jedna "borba za riječi" u kojoj se postavljaju "riječi kao oružje". Političke historije daju se potpuno opisati kao dominacija određenih riječi i izreka. Politički PR se u ovoj oblasti konfrontira sa ozbiljnim problemima u kojima prevladavaju pitanja političke etike, mišljenja su njemački teoretičari. Istorija je svjedok odlučnih suprotstavljanja pojavi neke nove tehnike koja uznemirava čuvare starog znanja još od dijaloga Fedre i Sokrata, odnosno retoričke rasprave koje je zapisao Platon u Fedri oko 370. g. p.n.e. Kada se pokušavaju razraditi neke osnovne misli iz 800 godina duge povijesti teorije i prakse retorike, nezaobilazni su i Aristotelova Retorika, Ciceronova (De Oratore), Qvinitilianova (Institutio oratioria) i Augustinova (De doctrina christiana). Jer, klasična retorika (nauka o govoru, riječitosti) važi kao govornička spretnost zasnovana na empiriji, tj. iskustvu, odnosno, to nije ništa opipljivo već vještina uvjeravanja, argumentizovanja.

Od publicističkog uvjeravanja i nauke o govoru i publicistici te nauke o komunikaciji, preko pisane riječi do „kolosalne moći televizije danas, čak se može reći da je ona potencijalno najvažnija od svega. I biće tako ako nastavimo da podležemo njenim zloupotrebama. Televizija je zadobila suviše veliku moć u krilu demokratije. Nijedna demokratija ne može da preživi ako se ne stane na kraj te svemoći" - kako predstavlja fenomen televizije i manipulacije čuveni filozof Karl Poper.

I teoretičari iz Njemačke smatraju da je public relations potreban kontakt sa govornonaučnim formulisanjem pitanja, gdje se interes usko povezuje sa retorikom i naukom, da treba djelovati informativno ali ne suvo, angažovano a ne zahtjevno, da bude bogat alternativama ali ne bombastičan, dobro razumljiv ali ne u otrcanim fazama. I na kraju istaknimo i da treba izbjegavati pomodarstvo u korišćenju naziva o govoru, posebno lingvistike/ retorike i odnosa s javnošću i to kroz sljedeće karatkeristike: razvoj PR "govora" za nagovaranje, za razliku od govora reklame i propagande; održavanje stila govora stvarnosti; truda za govornu jasnoću i razvoj PR specifičnih formi pojednostavljivanja.

Suštinski, osim potpunog distanciranja od govora reklama i propagande PR govor trebao bi pokušati PR iz angloameričkog jezika i govora umjesto "rad sa javnošću" na njemačkom ili odnose

7 Popper, K. (1994) La television:un dnager ppour la democratie, Paris 
s javnošću u našim govorima i jezicima. Uostalom najvažnija je suština i bit pojma, a ne izraz.

\section{Kauzalitet komunikacija i PR-a}

Nauka komunikacija i problematika istraživanja PR-a prošle su mnoge razvojne faze da bi došli do postojećeg odnosa, odnosno aktuelnog shvatanja da određenu stručno-disciplinarnu neodređenost nauka komunikacija dijeli sa PR istraživanjem i kroz poseban odnos sa praksom i isticanjem javnih komunikacija: nauka o publicistici, žurnalistici, medijima...Uostalom, komunikacija se smatra privilegovanim ključem za tumačenje čitave istorije ljudskog roda. ${ }^{8}$ Razvoj sredstava masovne komunikacije pratila je globalna pojava snaženja javnog mnijenja, a time i PR-a.

Kada je riječ o ranim radovima teoretičara komunikacije i javnog mnijenja kroz prizmu uloge masmedija Valter Lipman je, pišući o „spoljnjem svijetu i našim slikama u glavi“, prvi istakao važnu ulogu medija da nam pomažu da stvorimo ,,vjerodostojnu sliku svijeta koji se nalazi izvan našeg dometa i direktnog iskustva. Nakon Shannon-Weaverovih istraživanja i modela komunikacijskih procesa diseminacije nasuprot komunikaciji i brojnih elemenata komunikacijskih modela, nastalih u drugoj polovini prošlog vijeka, kao i strategija PR-a (rezultat komunikacijskih i ispitivanja javnog mnijenja), nove medijske tehnologije su proizvele nove efekte $\mathrm{i}$ izazove.

Ređale su se teorije o „beskrajnim“ medijskim efektima i dejstvima od „modela potkožne injekcije“, preko „dvoetapnog toka“, „teorije spiralne tišine“, da bi Maršal Makluan tezom „Medij je poruka“ najavio kraj Gutenbergove galaksije i prozreo budućnost medija i dometa civilizacije u kojoj egzistiramo i početkom (n)ovog milenijuma.

Komunikacija je postala jedna od ključnih pojmova današnjeg doba i da se nauka o komunikacijama obrađuje interdisciplinarno kao i da se i PR smatra i istražuje kao specijalna oblast današnje komunikacije među ljudima, mišljenja su mnogi komunikolozi i teoretičari koje pobrajaju Ronnerberger i Ruhl u svojoj "Teoriji odnosa sa javnošću”. Ovi autori ukazuju na: opštu nauku o komunikacijama i teoriju komunikacija, odnose između individualnih i masovnih komunikacija, a posebno za opštu komunikaciju organizacije, formu i način komunikacije, istraživanje neverbalnih načina komuniciranja od jezika do muzičke komunikacije, medijske komunikacije kao komunikacije zavisne od organizacije, komunikacije uvjeravanja i

8 Gocini, G. (2001) Istorija novinarstva, Beograd: Clio 


\section{VELIZAR SREDANOVIĆ}

nagovaranja (savjetovanje), tokove komuniciranja PR-a, djelovanje (psihički efekti), rezultate (društveni ciljevi), zabavu, istraživanje mas medija i PR, politiku komunikacije, odluke u PR praksi, medijske tehnike i na kraju žurnalizam i žurnalistiku, međusobni odnosi žurnalizma i žurnalistike prema PR, kroz teorije i istraživanja. ${ }^{9}$

I na kraju razmatranja nauke komunikacija i problematike istraživanja PR-a da se zaključiti da masmediji i komunikacije nisu puki prenosioci samo informacija već imaju značajnu ulogu da, kao i PR, definišu odnose i društveni kontekst u okviru koga egzistiramo. Otuda i vrlo interesantno zapažanje Filipa Bretona: „Ono što sada, krajem XX vijeka, nazivamo komunikacijom koja više ne razlikuje sredstva od ciljeva, zaista, predstavlja lijek za sve, jednu ideologiju, utopiju". Ovakav stav Fransis Bel u svojoj knjizi Moć medija veoma efektno komentariše da bi pod takvom vladavinom utopije novi kredo mogao biti "Komuniciram, dakle jesam". Uostalom, zar XX vijek nije bio u znaku komunikacija?

\section{$P R$, sociologija i istraživanja}

Između sociologije i PR-a postoji uzajamna prirodna naklonost, kao između nauke o komunikacijama i odnosa sa javnošću, a sociologija ima poseban naučni doprinos PR-u kroz istraživački rad i "preuzimanjem" sociološkog znanja o društvu i njegovim oblastima. Od različitih koncepcija, orijentacija i zadataka moderne sociologije, te problema istraživanja i PR teorija, ona prije svega informiše o: društvenim i kulturnim promjenama, raščlanjenju društva (po socijalno statističkim grupacijama, socijalnim slojevima, klasama, organizacijama elitama, familijama...) hijerarhijskim i kooperativnim strukturama u organizacijama (države, privrede, kulturnih institucija), o prevolađujućim slikama društva, formama socijalnih odnosa (u različitim grupacijama) i rukovođenja, upravljanja, kontrole među organizacijama svih vrsta...

Razumijevanje i uspjeh PR-a zavise od toga koliko su opšte poznati normiranja i institucije jer urastanje pojedinca u "već postojeću" institucionalnu socijalnu strukturu vrši se socijalizacijom i usvajanjem kulture, ali i personalizacijom. Public Relations kao socijalni sistem moraju pokušati pomoći indirektno procese socijalizacije ukoliko upućuju na njihove ciljeve i nastoje uskladiti svoj strukovni rad, ali ne i proizvesti uniformnog konformistu, psihički pasivnog čovjeka, sa kojim se može manipulisati. Vladajuće mišljenje u sociologiji da u aktuelnom

9 Sredanović, V. (2005) Komunikacija-motor civilizacije, Agora br.14, Podgorica 
pluralističkom društvu dominira konflikt a ne harmonija podupire i francuski sociolog Pjer Burdije ilustrativnim primjerom "negativnih intelektualaca" koji se ne dokazuju u akademiji..." već na televiziji čije se trostruko mjerilo kvaliteta, sadržano u sloganu brzo, kratko, jasno, prevodi u sintetički pokazatelj-površno". ${ }^{10}$

Metode, tehnike i razvoj teorija empiričkog socijalnog istraživanja su interesantne kod PR-a od kontroverzi oko kvantitativnog i kvalitativnog istraživanja, mjernih metoda i teorija utemeljenih u Njemačkoj i Zapadnoj Evropi sve do teorija američkih socijalnih psihologa o efektima istraživanja medija (prije svih Paula J. Lazarsfelda) koji su osporavali formulacije evropskih teoretičara društva, poznate Frankfurtske škole. Nasuprot tvrdnjama Adorna i Horhajmera o medijima kao moćnim instrumentima društvene kontrole, "preko kojih se masama nude lažna zadovoljstva, čime se razaraju ljudska i individualnost i sposobnost kritičkog mišljenja", američki psiholozi su lansirali teoriju "da su mediji demokratske institucije, koje svakoga uvode u glavni tok kulture”. O značaju istraživanja u funkciji public relations-a bi se moglo mnogo pisati kao i o vrstama, predmetima i temama istraživanja (od osnovnih do primjenjenih) u PR-u. Naravno, i o motivima, procjenama i kontrolama, ne samo auditorijuma, istraživanja, komunikacija i organizacija...jer istraživanje je moguće klasifikovati po više kriterijuma, pa i istraživanja u PR-u. Funkcije istraživanja u odnosima sa javnošću se ogledaju u potvrdi pretpostavki o javnom mišljenju, razjašnjavanju pitanja i osjećanja o kojima postoje protivrječni podaci i rasvjetljavanju nejasnoća koje se javljaju kod odnosa s javnošću.

Potreba istraživanja za odnose s javnošću stalno raste a prakticistički metodi istraživanja imaju prednost u funkciji public relations-a, jer "Public relations nije samo publicitet. To nije samo slanje informacija i poruka. To čak nije samo komunikacija. PR je primanje informacije i interakcija."- profesor David J. Pincus.

Istraživanje mišljenja gleda se kao djelomično područje socijalne psihologije a težište sociologije i socijalne psihologije, koje je relativno za PR, su teorije socijalnog učenja. One se, ipak, zasnivaju na istraživanjima koja su, opet, plod saradnje sa istraživačkim institutima i agencijama za ispitivanje javnog mnijenja. Međutim, probleme, teme, specijalna pitanja i formiranje ciljnih grupa može pripremati samo PR osoblje, dok su instrumentariji i tehnika istraživanja prepušteni institutima.

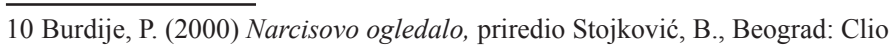




\section{VELIZAR SREDANOVIĆ}

\section{PR, ekonomske nauke i marketing}

Iako je odavno PR posmatran kao bitni dio ekonomske nauke, koincidencija razvoja i širenja ekonomske nauke o preduzećima i public relations-a između dva svjetska rata može se istaći osobenost PR-a kao "djeteta industrijskog vijeka". Razmatrajući odnose ekonomske nauke, marketinga i odnosa s javnošću, prije svega, prezentiraćemo činjenicu da se ekonomska nauka o privredi zanima ne samo za organizaciju i tržišta preduzeća nego i za probleme rukovođenja i odlučivanja, investicija i finansiranja. Praktično, bez poznavanja teorija ovih činilaca, koje smo nabrojali, ne mogu se koncipirati PR firme.

Da li su odnosi s javnošću primarno sastavni dio ekonomske nauke o preduzećima ,posebna oblast kao marketing, njegov podsticaj ili samo instrument privredno ekonomske politike komuniciranja, pitanja su koja su ostala nerazjašnjena u potpunosti i nakon koncepta vezanog za marketing (1950-tih iz USA ) i rukovođenje u preduzećima, koji je umjesto težišta na proizvodnju, orijentaciju pomakao na tržište (Kotler 1982, Mefert 1986, Nieschlag i drugi od 1968. do 1985). Ovi predstavnici tipičnog “čisto ekonomskog načina gledanja” koji smatraju da PR mogu profitirati od strategije prometa i reklame politike preduzeća usmjerene na aktivnosti sistema okoline, naravno, orijentišući se na kupca.

U tom kontekstu, mjere i rezultati istraživanja tržišta, psihologije prodaje, politike proizvodnje koriste se za PR strategije i PR planiranje i trebaju da imaju zajedničke ciljeve "inžinjering za zadovoljenje kupca", po Kotleru i Leviju. Interesantan je stav Nieschlaga, da se mora izbjeći utisak da se PR skupa sa reklamom i zahtjevima prodaje shvata kao "politika komuniciranja" preduzeća i na taj način reducira na planske mjere javne komunikacije ili sav PR bi trebalo da stoji u službi marketinga. Za promjene razumijevanja PR-a do samoodređenja PR-a 50-tih godina najviše, je učinio Carl Hundhausen koji je u početku public relations označavao kao "reklamu za javno povjerenje"(1951. godine), da bi 1974., kroz pojam publiciteta, PR odredio i obrađivao kao "samostalnu naučnu disciplinu". Često se iz PR i reklama zbog istovrsnih instrumenata i formi organizacije istraživanja tržišta i korištenja istih sredstava komunikacije može steći utisak da se radi o istome. Međutim, ciljevi i funkcije odnosa sa javnošću su mnogo raznovrsnije uprkos primjeni sličnih ili istih alata i struktura komuniciranja reklame i marketinga. 
Težnje da se odnosi sa javnošću podvedu pod marketing ${ }^{11}$ su pod uticajem menadžera u firmama prisutne (jake) i danas, jer zagovornici marketinga zahtjevaju veoma široka ovlašćenja iako ne pokrivaju interne odnose među zaposlenima, društvene odnose i parlamentarne veze i druge oblike i aktivnosti odnosa s javnošću. Istina je da marketing, oglašavanje i odnosi s javnošću imaju mnogo zajedničkog, ali ne bi trebali da preuzimaju aktivnosti koje ih upravo razlikuju. No, to ne znači da se nekada u praksi, aktivnosti PR-a i marketinga neće preklapati. Kao potvrda ove teze i aksiom broj 6 Paula Watzalavicka (1990): “Osnov za svaku PR strategiju je marketing filozofija kao konsekventni način razmišljanja ali i djelovanja u kreiranju odnosa sa drugom stranom (okruženjem) koji polazi od otkrivenih (istraživanjima) potreba i želja. Međutim, ne dobija samo PR od marketinga nego i marketing koristi PR metode i instrumente za ostvarivanje svojih tržišnih i proizvodnih ciljeva".

I pošto je nesporno da su osnovna znanja ekonomske nauke pretpostavka za svaki PR, jer po Fliegeru (1981.)“ samo njihovo usvajanje može osigurati da se stalno prisutne informacije o pojedinačnim i opštim privrednim problemima u modernim visoko razvijenim, radom intenzivnim društvima..." Dodali bi samo da to važi i za društva u tranziciji gdje kod javnih ustanova i državne uprave ne postoji dovoljno sazrela svijest o ulozi PR-a pa se uzajamni odnosi između PR-a i privrede inače relativiziraju kada su u pitanju društveno razumijevanje i komunikativni elementi. Zato se događa da su važni zakonodavni procesi u praksi poput privatizacije nerazumljivi i neprihvatljivi za javnost, a PR praksa najteži zadatak javnog komuniciranja u takvim društvenim uređenjima. Ili se pribježište traži, opet, u tradicionalnim shvatanjima ekonomske nauke i prakse koji i ove probleme posmatraju u perspektivi odnosa cilj-sredstvo, a PR hoće da svedu u svoje okvire.

\section{Politikologija, upravljanje i PR}

Nakon ili prije sociologije, socijalne psihologije i ekonomskih nauka, odnosi s javnošću, a naročito politički PR (political public relations) kroz politikologiju i nauku o upravljanju imaju stalnu osmišljenu dvosmjernu komunikaciju pojedinca, grupe, organizacije, partije ili stranke sa javnostima od interesa za njih. Uposleni u public relations na državnim poslovima ili u upravljanju državom, partijom, institucijom, vlašću... moraju dobro znati način funkcionisanja modernih političkih sistema, ali, prije svega, moraju poznavati sve komplikovaniji rad ne samo

11 Sredanović, V. (17. juli 2005) Komunikacija-motor civilizacije, Agora br. 14, Podgorica 


\section{VELIZAR SREDANOVIĆ}

partija, parlamenata i vlada, već i nevladinih tzv.neprofitnih organizacija.

Razvojem uprave, politika je jedan djelatni oblik života, prema Karlu Manhajmu, ${ }^{12}$ vještina vladanja praktičnih političara (Vladalac), prema Nikoli Makijaveliju i "upravljanje u višesmislenom pojmu ovog izraza", prema Ljubi Tadiću, ${ }^{13}$ spada u trajne teme, ne samo akademskih organizacija, nauke, nego i savremene prakse, pa i PR prakse i moderne demokratije.

Scott Cutlip, Allen Center i Glen Broom, vodeći američki teoretičari odnosa s javnošću, ističu kako je nemoguće razdvojiti vlast od politike, ali i uloge odnosa s javnošću u politici i vlasti koje su neraskidivo povezane. Njemački teoretičari, predvođeni Ronnerbergerom, smatraju da, analize iz teorije demokracije mogu, skupa sa PR istraživanjem, odlučujuće doprinijeti razumijevanju komplikovanog spleta zavisnosti u procesu demokratskog stvaranja, volje, ali i odluka i upravljanja u provođenju kod državne volje i aktivnosti javne uprave. Postavlja se i niz pitanja među kojima i kako stvarno funkcioniše višepartijska demokratija, kako rade rukovodstva partija, kako djeluju unutar parlamenta, kako vrše uticaj u institucijama društva, naročito u važnim medijskim sistemima?

Javnosti od političkog interesa su, prije svega, kompletno (ne) biračko tijelo: birači, potencijalni birači, apstinenti, članovi partija i stranaka, simpatizeri, profesionalci u strankama i partijama, mediji, novinari, država i njeni službenici, međunarodna javnost. Dakle, svi koji se nalaze na tom specifičnom tržištu političkih ideja.

"O političkoj javnosti za razliku od, na primjer, literarne, govorimo ako se javne diskusije tiču predmeta koji su povezani sa praksom države. Državna vlast je u neku ruku kontrahent političke javnosti, ali ne i njen dio. Doduše, ona važi kao javna vlast, ali atribut javnosti zahvaljuje svome zadatku da se brine za javno, tj. zajedničko dobro svih pravnih sudrugova",(Kultur und Kritik, Frankfurt/Main, 1973) citira Jirgena Habermasa Tadić i dodaje, „kako je u tom smislu javnost sfera koja posreduje između društva i države, u kojoj se formira publika koja je nosilac javnog mnijenja“.

Poznavanje političko-administrativnih i društvenih sistema je, prema njemačkim teoretičarima, preduslov kod koncepcije PR strategija u oblasti ekonomije, a iznad toga u društvu i kulturi. Opšta teorija PR-a da se zastupati samo kada je kompatibilna sa teorijama politike, uprave, saveza modernih partijsko-

12 Manhajm, K. (1968) Ideologija i utopija, Beograd

13 Tadić, Lj. (1988) Nauka o politici, Beograd: Rad 
demokratskih sistema pluralističkog društvenog stanja. No, i pored svega navedenog o nauci politike i upravljanja i odnosa sa javnošću, postoje velika neslaganja oko pitanja da li je i lobiranje (uključeno u demokratske procese parlamentarnog i političkog sistema) legitiman dio odnosa sa javnošću. Lobiranje, nastalo u kolijevci parlamentarizma u Britaniji, odavno se uvriježilo u Evropskoj zajednici. U rasprostiranju od Vajthola, preko poslanika parlamenta i Doma lordova, pa do poslanika Evropskog parlamenta i službenika Evropske komisije u Briselu, o čemu piše Sem Blek u Odnosima s javnošć $u^{14}$, lobiranje je odavno postalo legitimno. Prema Bleku, lobiranje se sastoji od tri elementa: 1. razumijevanja (upozorava na probleme, daje osnovu za strategiju i taktiku i identifikuje potencijalne (ne)prijatelje) 2. komunikacije (da se u pravom trenutku idealnoj ciljnoj grupi emituje dobro komponovana poruka) 3. presinga (kada pravi ljudi preduzimaju potrebne aktivnosti u najpogodnijem trenutku).

Lobiranje je odavno postalo javno. No postoje PR kompanije i lobisti koji djeluju u tajnosti budući da stručnjaci PR-a smatraju da najbolji PR ne ostavlja nikakve tragove, a komunikaciju shvaćaju kao instrument za kontrolu "društvene temperature" Tako moćni, posredstvom medija, kreiraju i u centrima PR-a stvaraju medijsku realnost kakva im odgovara. Stimulacijom želja "društvena temperatura" može se povećati, a u suprotnom komunikacionom smjeru - širenjem pozadinskih informacija "temperatura" se može smanjiti. I tako unedogled. Ipak, promjenljivi trendovi PR kompanija i lobista koji djeluju u tajnosti, poput onih iz grupe Bilderberg, koji svoje skupove održavaju van dometa javnosti, tjeraju na nove taktike i poduhvate istraživačkog novinarstva, kao budnog oka javnosti, koji se opire arkanskim krugovima moći.

\section{Odnosi s javnostima, država i novinarstvo}

Manifestno kroz promocije, suštinski kroz promotivne strategije Odnosi s javnostima su (p)ostale u centru pažnje ne samo u svijetu biznisa tj. savremenog načina poslovanja i politike, već odavno razvijenih država i vlada koje drže do prestiža. Paralelno, moć odnosa s javnošću u ekspanziji je kao moć medija, i njihov uticaj u društvu i na društvo su toliko isprepletani da se može govoriti o obostranom uporednom uticaju na donošenje važnih političkih odluka. Razmatrajući odnos moći PR-a i novinarstva, promocija i medijskih i promotivnih strategija, Dejvid Miler, u knjizi Uvod u studije medija, je istakao ulogu liberalne pluralističke teorije, prema kojoj mediji obezbjeđuju javni prostor u kome se distribuiraju informacije i informišu javnost, a

14 Blek, S. (1997) Odnosi s javnošću, Beograd: Clio 


\section{VELIZAR SREDANOVIĆ}

slobodni mediji funkcionišu kao pas čuvar koji motri na poteze vlade. Uprkos tome što takav stav Miler ${ }^{15}$ pospješuje sintetizovanom tezom kako: "Slobodna konkurencija u borbi za medijski prostor i političku moć garantuje da će se u medijima čuti različiti glasovi”, proisteklom iz učenja brojnih teoretičara (Gansa 1980; Blumera i Gurevitcha 1995; Sigala 1986.), kontra marskističkoj teoriji koja medije vidi kao sredstvo klasne kontrole, a novinare kao reproduktivce zvaničnih poruka. Na taj način mase su indoktrinirane a stabilnost kapitalizma obezbjeđena, ili što bi narodski kazali „i vuk sit, i ovce na broju”. Međutim, marksističku teoriju koju, poput Halla (1978), nazivaju i „strukturalilstičkom" jer njeni zagovornici tvrde da u medijima oni koji imaju moć dobijaju „strukturno prvenstvo" i primarno definišu tokove masmedijskog izvještavanja, Miler dopunjava pretpostavkom da kontrola nad informacijama znači isto što i isticanje moći u društvu. Ipak, obje ove teorije su „medijacentrične” sa aspekta razumijevanja i analize odnosa s javnošću i države, tj. promotivnih strategija vlade, interesnih ili grupa za pritisak i njihovih odnosa prema medijima i moći u društvu. Poslije svega, imajući u vidu globalnu krizu kapitalizma aktuelizuju se marksističke teorije, i dileme Habermasove ali i Kinove „refeudalizacije javnih sfera"...Uostalom, zar se ne nameće državni intervencionizam (SAD i EU) u finansijama i ekonomiji, u suzbijanju ekspanzije svjetske recesije, čime jača moć, tj. vraća se na nekadašnje pozicije uticaj države i vlade.

I letimičnom retrospektivom razvoja propagande i odnosa s javnostima, te javnog mnijenja, primjetno je da se u prvim decenijama dvadesetog vijeka, zahvaljujući širenju pismenosti, demokratije (prava na glas, političkog i sindikalnog organizovanja okupljanja...) i ubrzanom razvoju tehnologije komunikacionih sredstava, paralelno odvijaju razvoj propagande i PR (naročito u ratovima, nemirima u kolonijama ili protiv sindikata... ). Britanski Foreign Office i vojska su još tokom Prvog svjetskog rata imali portparole, da bi poslije Drugog svjetskog rata preplavili britansku administraciju kao i u SAD pedesetih prošlog vijeka, i u biznisu i u politici, kada je nastala prava najezda PR poslenika. Najznačajniji pomak u razvoju odnosa s medijima i veza u parlamentu nastao je upravo razvojem i masovnim prihvatanjem elektronskih medija, posebno televizije. Do tada je bila u upotrebi uobičajena terminologija „odnosi s štampom”, a onda je nastupila era „odnosa s medijima”, a „konferencije za štampu” zamijenile su "konferencije za novinare". PR su izvor brojnih vijesti i komentara u najprestižnijim dnevnim novinama od Londona, Vašingtona, Moskve, Berlina, Pekinga, Pariza, Tokija...

15 Isto., str. 114. 
Odnosi s javnošću bilo koje vlade ili vlasti, bez obzira na državno uređenje, tj. društveno-politički sistem svojim aktivnostima obuhvaćaju, između ostalih, javno informisanje i komunikaciju i, naravno, javne poslove, sve za dobrobit svojih građana. Međutim, po uzoru, na građane SAD, zbog nemogućnosti da utiču na politiku vlasti, i građani evropskih i drugih visokorazvijenih zemalja koje, ipak, pripadaju državama sa demokratskom tradicijom, sve manje izlaze na izbore. Pojava javne građanske apatije proizvela je armiju razočaranih glasača i u Evropi, ali rasplamsala vječiti sukob vlasti, tj. političara $s$ jedne, a većine građana i medija koje ne kontrolišu vlasti, s druge strane. Aktuelizovala se teza o medijima i novinarima kao psima čuvarima demokratije, a negdje je vlast toliko nemoćna u toj borbi da čak gasi javni tv servis, odnosno, nacionalnu televiziju, kao u Grčkoj, što je presedan u Evropskoj uniji.

Miler i Dinana (2000) navode da je slobodno tržište za vrijeme Margaret Tačer i vladavine konzervativaca omogućilo da, između 1979. i 1998. godine, industrija konsultantskih firmi u oblasti PR-a u Velikoj Britaniji naraste čak 11 puta. Politička scena u SAD izrodila je i prve spin doktore. Laburisti Tonija Blera, djelatnost spin doktora, anketara i prezentacija doveli su do zenita u poslednjoj deceniji prošlog vijeka uspjevši da prepakuju stranku u novu političku ambalažu, da bi, s pozicija vlasti, poslije 1997. godine, napravili masovnu čistku čelnika informativnih službi u Vajtholu. Tako Moloney (1996) ističe: „S rastom odnosa $\mathrm{s}$ javnošću došle su i bezbrojne specijalizacije, kao što su odnosi s medijima (media relations), javni poslovi (public affairs), bavljenje društvenim problemima (issues managment) i lobiranje (lobbyng)." "16 Tamnu strana lobiranja otkrila je afera „keš za pitanja” (cash-for-questons), u kome je otkriveno da neki polanici laburanata u parlamentu tajno rade za prikrivene interese pojedinih lobija (Greer Leigh i Vulliamy 1997) ili čak interese pojedinaca, poput „slučaja guvernera Blagojevića” u Kongresu SAD. No, da ovakav, porijeklom ,gore naše list” sa eks jugoslovenskih prostora, nije usamljen u (zlo)upotrebi interesa pojedinaca, zbog enormnog bogaćenja, prilikom lobiranja, ilustrativni su primjeri na hrvatskoj (sanaderizacija), slovenačkoj (slučaj Janša), srpskoj, crnogorskoj i bosansko-hercegovačkoj političko-ekonomskoj sceni...

Prema podacima Milera i Dinana (2000) samo 1995. godin, 150 vodećih konsultantskih firmi zaradile su za PR 440 miliona funti, a promotivne aktivnosti britanske vlade u službi za informacije i komunikacije provodilo je 1.200 portparola. Aktivnosti odnosa s javnošću i lobiranja i uticaj centara moći proširio se sa

16 Isto, str. 117. 


\section{VELIZAR SREDANOVIĆ}

nacionalnih država na transnacionalni nivo (Brisel i Starzbur, $\mathrm{tj}$. institucije Evropske unije) koji je postao meta raznih konsultantskih firmi i grupa za pritisak.

Globalizacija kapitala i institucija (Svjetske banke, MMF, STO...) izazvala je i globalne proteste od Sijetla (protiv STO), preko Praga (MMF), do Davosa(G7), krajem prošlog i na prelazu milenijuma, ali i u prvoj deceniji ovog vijeka, milenijuma. S druge strane, postoje i grupe za pritisak poput Greenpace, koje su van državnog domena ali takođe dugoročne. Istina, ne toliko institucionalno moćne ali sa određenim publicitetom itekako prisutnim u masmedijima i po veoma prepoznatljivim akcijama. No, država je centralno mjesto uticaja i kontrole ne samo nad javnim informisanjem nego i nad istraživanjima (ankete koje sugerišu pobjednika na izborima) i zvaničnom statistikom (friziranje podataka o nezaposlenima ili potrošačkoj korpi), pa sve do dezinformaciju u ratu... Takvim mehanizmima, vlade lako manipulišu javnošću putem brifinga, lobi sistemom preko kojih „cure povjerljive informacije”, a ne samo putem „vijesti dana” iz ,izvora bliskih vlasti”, za koje niko na kraju ne odgovara, a koje, opet, kreiraju javno mnijenje. U tom kontekstu, nastao je i radio SAD namijenjen inostranstvu „Glas Amerike”, poslije novinskih agencija, prvi globalni elektronski medij na svijetu.

Rijetko kada će se dogoditi, rivalitet, odnosno oprečnost, pa i kontroverznost $u$ jednoj vladi ili među državnim institucijama oko promocije ili javnog nastupa povodom neke političke provedbe ili podjele u izjavama za javnost zbog nekog slučaja. Istina, događalo se da povodom pojave salmonele i bolesti ,ludih krava" u Engleskoj da ministarstva zdravlja i poljoprivrede zauzmu potpuno oprečne stavove, pa čak i da se međusobno napadaju.

Za vrijeme Zalivskog rata 1991. godine, vlade Zapada su, posredstvom medija (prednjačio CNN) i PR kompanija (PR kompanija Hill and Knowlton angažovala je vlada Kuvajta), satanizovale Sadama Huseina, označivši ga kao glavnu prijetnju zapadnoj civilizaciji. Do njegovog vješanja su ga upoređivali sa Hitlerom. „Pametno” oružje zapadne alijanse koje je navodilo rakete sa, navodno, hirurškom preciznošću, sijalo je smrt ne samo po vojnim ciljevima u Iraku nego i po civilnom stanovništvu. Od ukupnog broja poginulih Iračana, najmanje četvrtina su bile civilne žrtve.

Sličnosti ne nedostaje i prilikom NATO bombardovanja Srbije, zbog Kosova i Miloševićeve politike 1999-te (kolateralna šteta u Grdelici i na drugim mjestima Srbije kada su stradali civili), pa čak i ničim izazvanim ubistvom djece na mostu u mjestu Murina u Crnoj Gori, takođe tokom akcije NATO alijanse „Milosrdni 
anđeo". Koliko je PR Bijele kuće uticao na moć medija u određivanju prioritetnih tema, ilustruju primjeri Klintonovih seks skandala sa Paulom Džons i Monikom Levinski, koje su, uoči predsjedničke kampanje, zasjenile sve tadašnje ratove SAD i socijalne probleme ove globalne super sile.

Uloga odnosa s javnostima svakim danom je sve napornija. Tim više, kada se ne samo građani SAD-a osjećaju prevarenim od svoje vlasti, već i znatan dio glasača u evropskim državama, jer su odavno prozreli političko takmičenje kao golu borbu za vlast, a ne za bolji standard i demokratske vrijednosti. Pošto je nemoguća misija odvojiti vlast od politike tako su PR i politika u neraskidivom odnosu, kao i političko lobiranje tj. modus vivendi ove, ipak, isplative profesije.

\section{Zaključak}

Lobiranje je odavno postalo javno, no postoje PR kompanije i lobisti koji djeluju u tajnosti, budući da stručnjaci PR-a smatraju da najbolji PR ne ostavlja nikakve tragove, a komunikaciju shvaćaju kao instrument za kontrolu "društvene temperature". Tako moćni, posredstvom medija, kreiraju, i u centrima PR stvaraju, medijsku realnost kakva im odgovara. Stimulacijom želja, "društvena temperatura" može se povećati, a u suprotnom komunikacionom smjeru i širenjem pozadinskih informacija "temperatura" se može smanjiti. I tako unedogled.

I na kraju razmatranja nauke komunikacije i problematike istraživanja PR-a da se zaključiti da masmediji i komunikacije nijesu puki prenosioci samo informacija već imaju značajnu ulogu, kao i PR, da definišu odnose i društveni kontekst u okviru koga egzistiramo. Medijski činioci, takođe, su važni za PR, jer je vrh vrijednosnog sistema rezervisan za tzv. ,provjerene informacije” i novinare „specijalce” koji koriste grupe za pritisak, Tako, recimo opozicioni lideri nastupaju kao svojevrsni uvodničari u procesu stvaranja afera i tzv. materijala za istraživačko novinarstvo. Zatim slijede „eksperti” iz određenih oblasti kao „svjedoci” prilikom ubjeđivanja javnosti...jer manjak stvarnog istraživačkog novinarstva nadoknađuju ,veliki brat”, sportski i razni zabavni prenosi „uživo”, te rijaliti šou da se „vlasi ne dosjete”. Preovlađuje svijet infotejmenta koji ne objašnjava nego stvara sliku ,realnog" svijeta, odnosno okruženja. No, ne treba smetnuti s uma da je zadatak slobodnih medija, pogotovo javnih servisa, da, uz informisanje građana, prioritet bude podsticanje na debatu.

Promjenljivi trendovi u sofisticiranom okruženju na svim nivoima i u, gotovo, svim oblastima razvijenih društava, doprinijeli su da industrija odnosa s javnošću i novinarstvo konvergiraju do mjere neprepoznatljivosti. U tom kontekstu, praktičnost 


\section{VELIZAR SREDANOVIĆ}

savremenog PR-a državnog sektora gubi u utrci sa komercijalnim medijima koje ne kontroliše i svakodnevno gubi na povjerenju građana... Očigledno je da moćni i bogati kada pripremaju strategiju i PR, čine to bez prisustva javnosti, poput onih iz grupe Bilderberg, potvrđujući tezu da je uvijek arkansko ili tajno odlučivalo o javnom, pa i na globalnom planu.

\section{LITERATURA:}

Bal, F. (1997) Moć medija:mandarin i trgovac, Beograd: Clio

Blek, S. (1997) Odnosi s javnošću, Beograd: Clio

Burdije, P. (2000) Narcisovo ogledalo, priredio Stojković, B., Beograd: Clio

Cutlip, S. M., Center, A. H. and Broom G. M. (2003) Odnosi s javnoš$c ́ u$,osmo izdanje; Zagreb: Mate

Gocini, G. (2001) Istorija novinarstva, Beograd: Clio

Habermas, J. (1973) Kultur und Kritik, Frankfurt: Main

Lorimer, R. (1998) Masovne komunikacije, Beograd: Clio

Manhajm, K. (1968) Ideologija i utopija, Beograd

Popper, K. (1994) La television:un dnager ppour la democratie, Paris

Ronneberger, Franz-Ruhl, Manfred, (1992) Theorie der public relations, Westd. Verl.Opladen

Sredanovic, V. (2007) Javnost i mediji u Crnoj Gori, Cetinje: Obod

Tadić, Lj. (1988) Nauka o politici, Beograd: Rad

Udovičić, R. (2007) Informatori s različitim ciljevima, Sarajevo: Media plan institut

Enciklopedija Britanika 1-10, knjiga 6, (2005) Beograd: Politika, Narodna knjiga

A Model for Public Relations Education for Professional Practice, (1982) IPRA Gold Paper,

No. 4, January

Sredanović, V. (2005) Komunikacija-motor civilizacije, Agora br.14, Podgorica

Sredanović, V. (15. juli 2005) Izmedju mogućeg i stvarnog, o pitanjima PR, ekonomske nauke i marketinga, Agora, Podgorica 


\title{
VELIZAR SREDANOVIĆ
}

\author{
Velizar Sredanović \\ Mediterranean University in Podgorica - Faculty of Visual Arts, \\ Podgorica, Montenegro
}

PR AND THE MEDIA - AGENTS OR COMPANY TAILORS

\begin{abstract}
Problems in conceptualization and definition of public relations and development of the PR profession from the 1930s have continued to this date, through the practical and theoretical efforts to prevent identifying of this profession-discipline with the news agencies and propaganda or with some other professions and disciplines like journalism, sociology, research, economics, marketing, politicology. Different approaches to defining the PR profession and the PR activities are inevitable as there is no single definition that would encompass all aspects of activities, tasks, trends, objectives and areas contained in this profession. A particularly interesting approach to PR is observed in the industry of journalism and in the state, not only at the global level and in developed societies but also in the transition countries. What is the role of PR and the media as powerful agents of media manipulations, the role of lobbyists and other tailors of the PR and the media, the role of a society, changing trends of PR companies and lobbyists who act from behind the scene (like those of the Bilderberg group), having in mind that PR experts believe that the best PR leaves no obvious trace?
\end{abstract}

Key words: public relations, communications, lobbying, journalism, public sphere 